This item was submitted to Loughborough's Research Repository by the author.

Items in Figshare are protected by copyright, with all rights reserved, unless otherwise indicated.

\title{
"'Gather up the Fragments, that nothing be lost": "Memorable" Women's Conversion Narratives'
}

PLEASE CITE THE PUBLISHED VERSION

http://humanities.miami.edu/publications/emwj/volume6.html

\section{PUBLISHER}

(C) Center for the Humanities, University of Miami

VERSION

VoR (Version of Record)

\section{LICENCE}

CC BY-NC-ND 4.0

\section{REPOSITORY RECORD}

Adcock, Rachel C.. 2019. "'"gather up the Fragments, That Nothing Be Lost": "memorable" Women's Conversion Narratives'”. figshare. https://hdl.handle.net/2134/14916. 


\title{
"Gather up the Fragments, that nothing be lost": "Memorable" Women's Conversion Narratives
}

\section{Rachel Adcock}

\begin{abstract}
7 he rise of separatist and Baptist congregations in the mid-seventeenth
century prompted the publishing of various women's life stories with the aim of preserving their precious experiences for the use of others. In times of religious persecution, such accounts would uphold and evangelize drooping spirits by collecting and displaying past memories of how God had revealed himself to believers. Katherine Sutton's A Christian Womans Experiences of the Glorious Working of Gods Free Grace, which was published at Rotterdam "for the Edification of others" in 1663, is a particularly engaging example of such experience.
\end{abstract}

Sutton had traveled across the seas from her native England with her family in search of religious toleration following Hanserd Knollys, the Particular Baptist minister who subsequently wrote the preface to her work. ${ }^{1}$ It was on this journey that Sutton's ship was wrecked on a sandbank where the "Master" of the vessel declared: "we are dead persons, and like to loose our lives." 2 Luckily, she and some others found a passage to the shore by a sandy strip, which caused her to rejoice and see their recovery as a sign for future generations: "As thy deliverance is, so shall Englands be, when they are brought to greatest streights, then will deliverance be from God," she declared (sig. C4). Both Sutton and Knollys saw the value of reproducing her text as a memorial of God's work for years to come: she had been preserved from harm and saw this as a sign that, though the godly in England were persecuted, they would soon be delivered out of harm's way. 
Sutton's written experiences are remarkable, in part because they comment extensively on the process of remembering and writing, and on the importance of preserving God's dealings with her. Although Sutton was delivered from her ordeal, the "papers of [her] experiences .... were lost" (sig. C3v $)$, and she attributed the whole event to God's displeasure with her for neglecting to publish the evidence of the free grace he had offered her. She vowed to reproduce this evidence, and, seemingly in answer to her prayers, she wrote that his "Spirit" came to be her "remembrancer to write again: and indeed it did so, not long after, in the night; both in song, and in prayer" (sig. C3v). Sutton attributes her remembrance of important memories solely to God, whose wish it was for them to be published for the upholding of others.

It is also the case that Knollys saw the profitability of Sutton's words, which were made up of prophesying songs as well as spiritual experiences, and sought to justify and promote them in his three-page preface. He specifically accounted for their "fragmentary" appearance, likening her experiences to "crumbs" from Christ:

When our Lord and Saviour JESUS CHRIST had fed many with a few Lo[a]ves, he commanded his Disciples to gather up the Fragments, that nothing be lost, John 6:12. And when God was pleased to poure out of this Spirit upon some of his faithful servants in our Generation, he had also some of his Handmaides [Joel 2:29], who gathered up the Crumes of that spiritual Bread, which the Lord blessed and distributed among his Disciples: Of which Number this holy Matron was one. $\left(\operatorname{sig}{ }^{*}{ }^{\mathrm{v}}{ }^{\mathrm{v}}\right)$

Using the image of crumbs left over from Christ's feeding of the five thousand, Knollys shows that no work of God (however small) should be lost. Even more significant is his validation of the publication of her work, in which she recovers the fragments of experience as a "handmaid" of God equal to the male disciples of Christ. The publishing of the experience, Knollys writes, was to the end "that God would not have these Fragments (which she hath gathered into her Basket) to be lost" (sig. * $\left.1^{v}\right){ }_{*}^{4}$ As a member of the gathered churches, Knollys promoted the idea that any memory or experience, no matter how small, should be recorded for the benefit of 
all God's people, to strengthen and edify them. That is not to say that literally every kind of experience was recorded through this permission; it is perhaps not surprising that women (and men) privileged certain memories over others, especially if it was for the purpose of joining a congregation. As oral, manuscript, and print circulation of these experiences increased, believers, consciously or not, knew what "crumbs" to observe and preserve in their accounts, making them seem rather conventional: "after all," as Catie Gill writes, "such narratives were used to assess 'fitness for admission' to a religious movement or sect." 5 Nonetheless, the variety of what appeared in the texts that followed is extraordinary.

The gathering of spiritual "crumbs," or episodes when the believer felt the presence of God, was an important part of Puritan life, especially for the Particular (or Calvinistic) Baptists of which Sutton was one. ${ }^{6}$ It was a requirement of these gathered churches that all potential members declare their experiences in front of the congregation to show the working of God on their hearts; some of these were then published as examples. The actual practice of recording these evidences of God's grace seems to have varied, and this is made clear when Sutton's text is compared with the better-known experiences of two of her female contemporaries. ${ }^{7}$ Whereas Sutton's first attempt at recording her experiences involved her remembering "thirty years experiences" (sig. C3), other women spent time writing regularly in the private space of their "closets." For instance, Anne Venn's experiences and meditations were discovered after her death in her closet, where she would often sit and write. Sarah Davy's prefatory writer - "A. P." - advised others to follow in his subject's practice of "self reflexion, Praying, Reading, Meditation, being her Morning and Evening exercise." Her spiritual experiences also consisted of "an account she used to take of her self of hearing the word" (sig. A $8^{v}$ ) which would preserve the points addressed in the sermon for later reference. Spiritual account books like these helped build up a store of encouragements that writers could refer to when confronted with life's trials, and buttressed their faith that they were one of God's elect. The importance of keeping such a record, including comforting passages from scripture, is expressed by the anonymous female writer of Conversion Exemplified: 
Many other comforts, at sundry times, from several Scriptures, were given in, fitted to the temptation that I was at such times under, which I have sinfully forgotten, the Lord pardon me in much mercy: Some I can give the better account of, because I wrote them in a Paper-book, which I have now by me. ${ }^{9}$

This anonymous female convert was on her deathbed when she dictated these lines, consulting her spiritual record to remind her of God's merciful love for her throughout her life. It is also important to recognize that she, and other female writers, thought that to forget a work of God (a "crumb" that could be preserved) was offensive and sinful. Davy berated herself for being apt "to forget the rock of my salvation" (sig. B5v), advising that believers record their experiences: "let not the gratious tast of his love slip out of thy remembrance but whilst he hath given thee life improve [enlarge] these mercies and the talent he hath lent thee [Matthew 25:14-30], to his own glory" (sig. C7). She then asks: "how many pretious evidences hast thou lost, for want of remembring them?" (sig. C7). ${ }^{10}$ Sutton seems more reluctant than women such as these to write her experiences, claiming that it took God to "set [it] upon my heart in the night, that I must writte" (sig. C3). Remembering "thirty years experience" was a daunting prospect for her, but the Lord encouraged her to continue with scriptural promises. She acknowledges that the published result was made up of fragments, and she pleads that old age has caused her memory to deteriorate: "I am an old fruitless branch [John 15:2, 6], my memory failes, and my understanding is so dull, that I am (and was at the best) a poor empty one" (sig. C3). This is surely Sutton expressing the modesty that was expected of a woman publishing, but it also testifies to the truth of her expressions: although much diminished, she implies that the memories have not been tampered with. ${ }^{11}$

Conversion narratives containing such records were valued highly by separatist and Baptist congregations because they confirmed existing evidence that they were part of God's chosen people: these "crumbs" of experience collectively testified to the validity of their emerging doctrines and practices and were preserved as precious treasures. So holy were these experiences thought to be, that Davy's work was described by her publisher 
as "part of the pretious Reliques, written with her own hand" (title page). Her experience was styled as a precious memorial and an example, and as a printed object it could be circulated within the congregations of saints, and beyond. Her life was called a "singular example" where she urged other believers to "forget not all bis benefits [Psalms 103:2]; let them be written on the table of thy heart for an everlasting memorial [Proverbs 3:3]" (sig. K2 ${ }^{v}$ ). Knollys wrote similarly of Sutton that God preserved the "Experiences in her heart, where it seemeth they were written, not with ink but by his holy Spirit [2 Corinthians 3:3]” $\left(\operatorname{sig}^{*}{ }^{*} 1^{v}\right)$. Sutton uses the most remarkable of these experiences, that she was the survivor of a shipwreck, as a foreshadowing of national events: just as she survived, assured of God's love towards her, the godly in England would also endure the religious persecution of the $1660 \mathrm{~s}$ and triumph. In such times, separatists and Baptists seemed to have used spiritual accounts like Sutton's as both memorials and proofs of God's love, and the more "fragments" or "crumbs" they could use as evidence, the more likely it was that they and their companions in faith would survive. Conversion narratives were the place to exhibit these "precious" memories for the comfort and edification of others, but also to uphold godly groups in the face of persecution.

\section{Notes}

1. Kenneth G. C. Newport, "Hanserd Knollys," Oxford Dictionary of National Biography (Oxford: Oxford University Press, 2004), 31: 967-70. Newport also shows that Knollys returned to England "via Rotterdam" in 1663/4 which matches both the preface and publication date of the work. Sutton records that religious persecution was intensified by the Act of Uniformity of 1662, when "our Teachers were removed into corners, and thrown into prisons." See Sutton, A Christian Womans Experiences (Rotterdam: Henry Goddæus, 1663), sig. D3 $3^{v}$, hereafter cited in the text. Her experiences were no doubt meant to comfort and edify her fellow sufferers.

2. Sutton, Experiences, sig. C4. For Sutton's biography see Elizabeth SkerpanWheeler's introduction to her text in Reading Early Modern Women: An Anthology of Texts in Manuscript and Print, ed. Helen Ostovich, Elizabeth Sauer, and Melissa Smith (London: Routledge, 2004), 173-75; Michael Davies, "Katherine Sutton," Oxford Dictionary of National Biography , 53: 397.

3. Sara Jones, a separatist woman who related her experience in front of the Laudian High Commission Court in The Relation of a Gentlewoman (Published by the author, 1642; Bodleian Library microfilm:), wrote through the night by candlelight, 
"having not time in regard of my duties of my familie" because she "could not spend much time of the day" (sig. B9). Sutton was a governess, although she had at least three children, two of whom died, and she advised others: "let all that fear God be encouraged to continue in, and not neglect family duties, for I have found by good experience many wrought upon by instructions and prayer" (Experiences, sig. D2v ${ }^{\mathrm{v}}$ ).

4. cf. Matthew 14:20, 15:37; Mark 6:43, 8:8; Luke 9:17; John 6:13.

5. Catie Gill, Women in the Seventeenth-Century Quaker Community: A Literary Study of Political Identities (Aldershot: Ashgate, 2005), 19.

6. The seventeenth-century Baptists had two main branches: Particular (or Calvinistic) and General (or Arminian) Baptists. The former adhered to traditional Calvinist thinking and the tenet that not all believers were part of God's elect and destined to go to heaven. Believers scrutinized their relationship with God and recorded their interpretations of providential events. These make up the bulk of published conversion narratives. See Owen Watkins, The Puritan Experience: Studies in Spiritual Autobiography (London: Routledge \& Kegan Paul, 1972); Her Own Life: Autobiographical Writings by Seventeenth-Century Englishwomen, ed. Elspeth Graham, Hilary Hinds, Elaine Hobby, and Helen Wilcox (London and New York: Routledge, 1989); Grace Abounding, with Other Spiritual Autobiographies, ed. John Stachniewski and Anita Pacheco (Oxford: Oxford University Press, 1998); Sheila Ottway, "Autobiography," in A Companion to Early Modern Women's Writing, ed. Anita Pacheco (Oxford: Blackwell, 2002), 231-47; and Maria Magro, "Spiritual Autobiography and Radical Sectarian Women's Discourse: Anna Trapnel and the Bad Girls of the English Revolution," Journal of Medieval and Early Modern Studies 34 (2004): 405-37.

7. Although important evidences were written down by either the experienced or their amanuensis, experiences were also circulated by word of mouth, both in the congregation and in the home. Anna Trapnel, on her journey to the West Country, spread her experiences through teaching those she met, which enabled her to commit them to memory: "I could not have related so much from the shallow memory I have naturally, but through often relating these things, they become as a written book, spread open before me, and after which I write." See Anna Trapnel's Report and Plea, or, a Narrative of Her Journey into Cornwal (London: Printed for Thomas Brewster, 1654), sig. G1"; Anna Trapnel, The Cry of a Stone, ed. H. Hinds, MRTS 220 (Tempe: ACMRS, 2000).

8. Anne Venn, A Wise Virgins Lamp Burning [. . .] Being the Experiences of Mrs. Anne Venn (London: Printed for E. [P.] Cole, 1658); and Sarah Davy, Heaven Realiz'd or the Holy Pleasure of Daily Intimate Communion with God (Published by A.P., 1670), sig. B1.

9. Conversion Exemplified; In the Instance of a Gracious Gentlewoman, Now in Glory (Canterbury Cathedral Library: London: 1663), sig. D7.

10. An Collins's most comforting "observation ... that her memory had registered" was that God was the "Rock of his Elect," and she writes of how she thought of preserving this most precious memory; see Collins, Divine Songs and Meditations (London: Printed by R. Bishop, 1653), sig. E3: 
In which review of mentall store,

One note affordeth comforts best,

Cheifly to be preser[ve]d therefore,

As in a Cabinet or Chest

One jewell may exceed the rest.

11. Other women's narratives were defended by their prefatory writers for being fragmented or "scattered." Jane Turner's husband thought her experience would be "profitable to some precious souls ..., though it be written but in a broken, scattering way." See Jane Turner, Choice Experiences of the Kind Dealings of God Before, In, and After Conversion (London: Printed by H. Hils, 1653), sig. B7 ${ }^{\vee}$. She preferred this method to exaggerating her memories, in case she wrote "something which was not" (sig. $\mathrm{C}^{v}$ ). Knollys defended the fragmentary quality of Sutton's experience, asking her readers not to be "offended with the broakenness of any matter, which thou mayest meet with," and compared the naturalness of her relating to that of the ebbing and flowing of the sea: "will any who lives upon the sea coast think the frequent Ebbing $\&$ flowing of the tyde a strange thing. Neither will any experienced Christian marvel at the suddain Ebbing and flowing of joyes, and sorrowes in the hearts of Saints" (sig. *2). 
